\title{
The Syrian Refugee Crisis: New Negotiation Chapter In European Union-Turkey Relations
}

\author{
Ulviyye Aydin \\ Izmir University, Turkey
}

\section{Conceptual Background}

Although it has occurred throughout history, migration has only recently become an important non-traditional security issue, having been absent from most government agendas even a decade ago. Today, however, it has become a priority for almost every government, a change which did not happen by accident.Anumber of factors have driven migration up the political agenda: in industrialized countries, an ageing population means labor market demands can no longer be met from the domestic workforce whereas less developed countries have an exponentially expanding unemployed youth population facing unsatisfactory working conditions,coupled with widening North-South economic and social disparities, andclimate change and other human caused catastrophes. Migration has been used to describe the the movement of people in very different contexts and situations, including invasion, conquest, displacement under force of arms, flight from natural disaster, mercantile outreach, colonial settlement and even slavery. ${ }^{1}$ More specifically, Oxford Dictionaries define migration as a movement of people to a new area or country in order to find work or better living conditions. ${ }^{2}$ The main reason for this definitionin contemporary usage isincreased international movements following the end of the Cold War and growing globalization of economic activities. Recent studies on migration mostly investigate flows from the South to the North in a search for better living conditions.

\footnotetext{
${ }^{1}$ International Organization for Migration, Essentials of Migration Management, Volume 1, Migration ManagementFoundation, Section 1.3 Migration and History in: http://www.rcmvs.org/documentos/IOM_EMM/v1/volume1.html, downloaded: 07/11/2015.

${ }^{2}$ Oxford Dictionaries, in: http://www.oxforddictionaries.com/definition/english/migration, downloaded: 07/11/2015.
} 
Everett Lee was the first to reformulate Ravenstein's migration theory in a pushpull framework, giving more emphasis to internal (or push) factors. These include lack of economic opportunities, religious or political persecution or hazardous environmental conditions. Pull factors include availability of jobs, religious or political freedom and perceptions of a relatively benign environment. Although migration for economic and social purposes can be considered as somewhat voluntary, keeping in mind these pull factors, in some situations people are forced to leave their homes and countries involuntarily.

Forced Migration Online (FMO) has adopted the multifaceted concept of forced migration, promoted by the International Association for the Study of Forced Migration (IASFM), which defines it as "a general term that refers to the movements of refugees and internally displaced people (those displaced by conflicts) as well as people displaced by natural or environmental disasters, chemical or nuclear disasters, famine, or development projects". ${ }^{3}$ Forced migration thus provides a new conceptualization for contemporary migration that includes multiple inter-related factors.

FMO identifiesthree separate types of forced migration in terms of causal factors: conflict, development policies and projects, and disasters. These are presented in Table 1.

Table 1. Types of Forced Migration

\begin{tabular}{|l|l|l|}
\hline Type & Main Reasons & Types of Migrants \\
\hline $\begin{array}{l}\text { Conflict- } \\
\text { induced } \\
\text { displacement }\end{array}$ & $\begin{array}{l}\text { Armed conflict, civil war, generalized } \\
\text { violence; persecution on the grounds of } \\
\text { nationality, race, religion, political } \\
\text { opinion or social group }\end{array}$ & $\begin{array}{l}\text { Internally displaced } \\
\text { persons; refugees, } \\
\text { asylum seekers }\end{array}$ \\
\hline $\begin{array}{l}\text { Development- } \\
\text { induced } \\
\text { displacement }\end{array}$ & $\begin{array}{l}\text { Development policies and projects, } \\
\text { large-scale infrastructure projects such } \\
\text { as dams, roads, ports, airports; urban } \\
\text { clearance initiatives; mining and defo- } \\
\text { restation; introduction of conservation } \\
\text { parks/reserves and biosphere projects }\end{array}$ & $\begin{array}{l}\text { persons; development } \\
\text { displacees }\end{array}$ \\
\hline
\end{tabular}

${ }^{3}$ Forced Migration Online,

in: http://www.forcedmigration.org/about/whatisfmhttp://www.forcedmigration.org/about/whatisf, downloaded: 07/11/2015. 


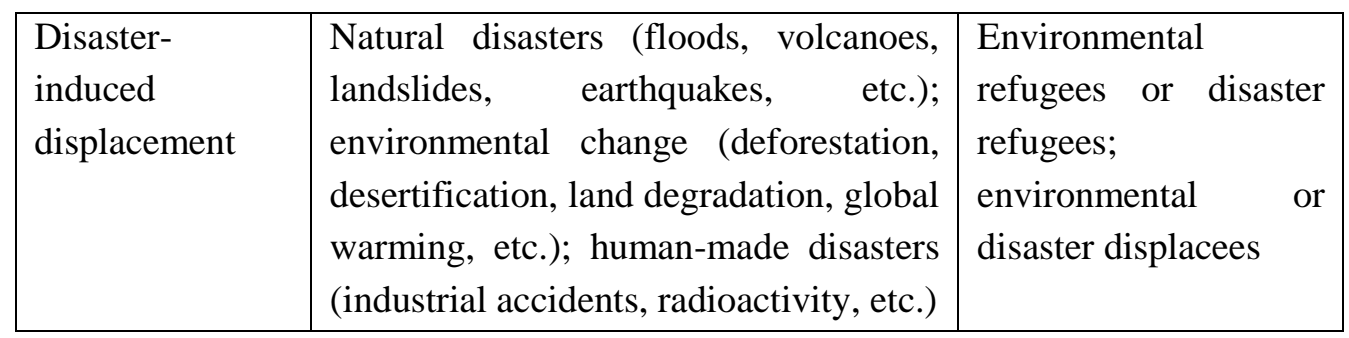

Source: FMO (2015) and author's elaboration

Since the end of the Cold War, the number of armed conflicts have escalated, with most being internal conflicts based on national, ethnic or religious separatist struggles, which significantly increased the number of refugees. Another more dramatic consequence is an increase in the number of internally displaced persons (IDPs) during such conflicts.

Globalization, particularly increased interdependence between countries and economic integration has prompted large development projects, including the construction of pipelines, railways and other transportation networks, which has also raised thenumber of IDPs. Investments by multinational companies and industrialized economies in less developed countriesare other factors behind these movements.

Climate change has intensified recently, having a serious impact on various geographical regions, making it another critical factor pusing people to leave their homes involuntarily.

In general, migration is deeply embedded in politics, economics, demography, sociology, psychology, nationality, ethnicity, culture and environment.Therefore, the critical question for states is how to manage migration effectively - both nationally and regionally - because, given these global trends, large population movements are inevitable. They are also necessary and, if managed properly, desirable as well.

\section{Conflict History}

After the collapse of socialist regimes at the end of the Cold War,several colored revolutions led to democratic reforms and good governance in these geographies. 
These democracy promoting proteststhen spreadto North African and Middle Eastern countries to become known as the Arab Spring.

The wave of Arab uprisings that began with the Tunisian revolution of January 2011 reached Syria in mid-March, when residents of the small southern town of Dara'a took to the streets to protest the torture of students who had put up antigovernment graffiti. President Bashar al-Assad at first wavered between force and hints of reforms. However, in April 2011, just days after lifting the country's decades-old state of emergency, his forces began the first of what became a series of severe crackdowns, sending tanks into restive cities as security forces opened fire on demonstrators. In retrospect, the attacks appeared calculated to turn peaceful protests violent to justify an escalation of force. After security forces opened fire on demonstrators, killing several, more took to the streets. The unrest triggered nationwide protests demanding President Assad's resignation as the government's use of force to crush the dissent merely hardened the protesters' resolve. By July 2011, thousands were taking to the streets across the country. Opposition supporters eventually began to take up arms, first to defend themselves and later to expel security forces from their localities. Attacks against the government spreadthroughout the country leading the United Nations to describe Syria as being on the verge of civil war by December2011. Although the Syrian National Govenment was formed to represent the opposition, President Assad and his supporters resistance hindered its recognitionby Western and Arab governments.

The current situation in Syria cannot be described as a single conflict because it has become now multifaceted with aspects that go beyond just tensions between rebel and government forces to include ethnic tensions, the involvement of world powers, jihadist groups, particularly Islamic State, and other terrorist organizations.

The cost of conflict in Syria is dramatic. Morethan 250,000 Syrians have lost their lives in $41 / 2$ years of armed conflict while over 11 million others out of an estimated pre-war population of about 23 million that already included refugees from Palestine and Iraqhave been forced from their homes as forces loyal to Assad and those opposed to his rule battle each other as well as jihadist militants from Islamic State. ${ }^{4}$ In the current chaotic situation, over 1 million Syrian refugees have registered as refugees since the beginning of 2013, with the daily flow of men,

${ }^{4}$ BBC News, "Syria: The Story of the Conflict", in: http://www.bbc.com/news/world-middle-east26116868, downloaded: 10/11/2015. 
women and children becoming one of the largest forced migrations since World War II. According to the United Nations High Commissioner for Refugees (UNHCR), the number of registered Syrian refugees is 4.287,293 which includes 2.1 million in Egypt, Iraq, Jordan and Lebanon, 2.2 million in Turkey, and over 26,700 in North Africa. ${ }^{5}$ According to UNHCR data, as shown in Table 2,the refugees are roughly equally divided between males and females, with similar proportions at different ages, indicating thatany Syrian who can isleaving the country.

Table 2. Demography of Syrian Refugees

\begin{tabular}{|l|l|l|}
\hline Male (49.7\%) & Age & Female (50.3\%) \\
\hline $8.9 \%$ & $0-4$ & $8.4 \%$ \\
\hline $10.8 \%$ & $5-11$ & $10.2 \%$ \\
\hline $6.6 \%$ & $12-17$ & $6.2 \%$ \\
\hline $22.1 \%$ & $18-59$ & $23.8 \%$ \\
\hline $1.3 \%$ & $60+$ & $1.7 \%$ \\
\hline
\end{tabular}

Source: UNHCR, in: http://data.unhcr.org/syrianrefugees/regional.php, downloaded: 07/11/2015.

A UN report from March 2015 estimated total economic losses since the start of the conflict at $\$ 202.6$ billion with70\% of Syrians now living in poverty;30\% in abject poverty. Syria's education, health and social welfare systemsare also in a state of collapse. ${ }^{6}$

A UN commission of inquiry, investigating alleged human rights violations since March 2011, has evidence that those on both sides of the conflict have committed war crimes, including murder, torture, rape and forced disappearances. Government and rebel forces have also been accused by investigators of using civilian suffering, such as blocking access to food, water and health services, as a method of war. ${ }^{7}$

\footnotetext{
${ }^{5}$ United Nations High Commissioner for Refugees, Syria Regional Refugee Response (updated 03 November 2015), in: http://data.unhcr.org/syrianrefugees/regional.php, downloaded: 07/11/2015.

${ }^{6}$ United Nations Development Programme, "Syria: Alienation and Violence, Impact of Syria Crisis Report 2015", March 2015, in: http://www.unrwa.org/sites/default/files/alienation_and_violence_impact_of_the_syria_crisis_ in_2014_eng.pdf, downloaded: 10/11/2015.

${ }^{7}$ United Nations Human Rights, The Independent International Commission of Inquiry on the Syrian Arab Republic, in: http://www.ohchr.org/en/hrbodies/hrc/iicisyria/pages/independentinternationalcommission.asp x, downloaded: 05/11/2015.
} 
The conflict has also drawn in major global powers in both support and opposition of Assad and the myriad rebel groups ranged against his regime and each other. On 30 October 2015, a world powers ${ }^{8}$ meeting in Vienna agreed to a nine-point plan intended to pave the way for a ceasefire in Syria, although they remain divided over what should happen to Assad.There was agreement at the talks on the need to preserve Syria's unity and secular nature, preserve its state institutes, protect the rights of Syrians of all ethnicities and religious groups, provide humanitarian aid, and continue providing aid to refugees and displaced people.Meanwhile, Syria's multi-sided war continues to threaten stability across the Middle East, which is already the world's most vulnerable region.

\section{Turkey's Involvement in the Syrian Refugee Crisis}

As the conflict enters its fifth year, Turkey's government has officially registered2.2 million Syrian refugees, or half the total refugee population, giving it the world's largest refugee population, as it shelters a significant number of Syrian refugees under temporary protection regulations.In an interview with CNN Turk, President Erdogan explained that Turkish government has already spent 8.5 billion USD supporting therefugees. ${ }^{9}$

Turkeybegan accepting refugees at the beginning of the civil war in March 2011, since when it has followed an open-door policy. It shares its longest common border with Syria, while various geographic and historical links also tie the two neighboring states together. ${ }^{10}$ Because the scale of human rights violations in Syria significantly increased in 2012, humanitarian aid needs haveincreased in line. According to the Directorate General of Migration Management of the Turkish govenment, 25 temporary accommodation centers have been established in 10

${ }^{8}$ Senior envoys from 17 countries, including Turkey, Italy, Britain, Lebanon, Iran, Jordan, Russia, Saudi Arabia, Iraq, Egypt, Germany, Qatar, France, the UAE, Oman, the United States and China plus the United Nations and European Union, were present in Vienna. Syria itself was not represented.

${ }^{9}$ Radikal, "Erdogan's Refugee Message To The Europe”, 13/11/2015, in: http://www.radikal.com.tr/turkiye/erdogandan-avrupaya-multeci-mesaji-1471665/, downloaded: 13/11/2015.

${ }^{10}$ Ministry of Interior of Republic of Turkey, Directorate General of Migration Management, "Syrian Nationals Benefiting from Temporary Protection in Turkey", updated: 09/07/2015, in: http://www.goc.gov.tr/icerik3/gecici-korumamiz-altindaki-suriyeliler_409_558_560, dpwnloaded: 14/11/2015. 
different southern and southeastern provincesto host 259,151 Syrians or $14 \%$ of the total.Besides, medical care, education and food supplies are provided for another $1.712,914$ Syrian citizens, or $86 \%$ of the total,living outside these accommodation centers in provinces throughout Turkey. Most Syrian refugees in Turkey come from Turkish-Syrian borderline areas where fighting has been intense.

The most debated aspect of the refugee issue is the legal status of the Syrian citizens coming to Turkey. Turkey is party to the 1951 Geneva Convention relating to the Status of Refugees and its 1967 Protocol, which is the key legal document defining who is a refugee, their rights and the legal obligations of states. However, Turkey includeda geographic limitation when signing the convention, under which itonly recognizes as refugees those people coming from Europe whereas those arriving from elsewhere can only stay temporarily under the status of asylum seeker.

Political and economic crises and deficiencies caused by internal and external conditions of Middle Eastern countries have led to both individual and mass migrations. As it is located at the crossroads of these human movements, both historically and geographically,primarily aimed to restrict human movements from the Middle East through its geographical limitation.

Syrian citizens cannot therefore gain refugee status in Turkey, being recognized only as asylumseekers under the temporary protection of the Turkish government according to Turkey's 1994 Refugee and Asylum Regulation. Because asylum seeker status excludes certain natural rights, Turkey introduced various special regulations and directives to help Syrians under temporary protection legally, including the right to stay in Turkey for an "acceptable" period of time and with "a temporary asylum right" until a third country accepts them as a refugee. Under its open door policy, Turkey has provided temporary protection for all arrivals, including those lacking a passport.

Legally, temporary protection status does not provide any long term prospects for Syrians in Turkey, leaving them without any security and infrastructure, based on temporary supply of their essential needs. Under this status,no Syrians have no legal right to work, even if they are qualified.However, the escalation of the war and lack of any hope of return has made it clear that most Syrians are likely to stay in Turkey permanently. This has forced Turkey to make some political changes in relation to 
their status. The Law of Foreigners and International Protection of $11 / 04 / 2013^{11}$ and the Temporary Protection Regulation dated 22/10/2014 ${ }^{12}$ clarified the status of Syrians, allowing them "temporary" integration with the labor market in Turkey. This gives Syrians holding the "temporary protection identity card"the right to gain a work permit. Publication of the Temporary Protection Regulation was especially important for determining the rights and obligations of Syrians in Turkey.

\section{The European Union's Involvement in the Syrian Refugee Crisis}

At $10 \%$ of the total number of Syrians who have escaped from their country, the number of Syrians arriving in Europe and seeking international protection continues to increase, although far less than in countries neighoring Syria.European countries recorded681,713 Syrian asylum applications between April 2011 and October $2015^{13}$ with 137,947 of these in 2014 alone. Serbia (including Kosovo) and Germany recorded 53\% of these, while 34\% were registered in Sweden, Hungary, Austria, Netherlands and Bulgaria, and 13\% in other European countries. Table 3 presents the number of Syrian asylum applications in 10 European countrieswhere there have been more than 10,000 between 2011-2015.

Table 3. Syrian Asylum Applications- Top 10 Countries

\begin{tabular}{|l|l|}
\hline Country & Number \\
\hline Serbia (and Kosovo) & 205,578 \\
\hline Germany & 153,655 \\
\hline Sweden & 93,268 \\
\hline Hungary & 71,845 \\
\hline Austria & 27,379 \\
\hline Netherlands & 22,159 \\
\hline Bulgaria & 16,167 \\
\hline Denmark & 14,533 \\
\hline Belgium & 12,030 \\
\hline Norway & 11,246 \\
\hline
\end{tabular}

Source: UNHCR, at: http://data.unhcr.org/syrianrefugees/asylum.php, downloaded: 06/11/2015.

\footnotetext{
${ }^{11}$ Republic of Turkey, Official Gazette No 28615, Law of Foreigners and International Protection No 6458, Approval Date: 04/04/2013, in:

http://www.resmigazete.gov.tr/eskiler/2013/04/20130411-2.htm, downloaded: 05/11/2015.

${ }^{12}$ Temporary Protection Regulation, in: http://www.goc.gov.tr/files/_dokuman28.pdf, downloaded: 05/11.2015.

${ }^{13}$ EU countries including Norway and Switzerland.
} 
Starting from 2014, but particularly during the summer of 2015, several EU member states faced a significant increase in the number of migrants arriving at their borders, with the majority needing international protection. While the summer is obviously the best season for migrants to make longer journeys, this was not the only reason why Syrians were arriving at the EU's external borders. Rather, a number of factors were involved: five years of civil war in Syria and the continued serious ISIS threat overstretched the hosting capacities of Syria's neighbouring countries so Syrians escaping there experienced increasingly poor living conditions. This was exacerbated becauseUN humanitarian agencies are on the verge of bankruptcy and unable to meet the basic needs of people in need of protection. In addition, these Syrians lost hope of returning to Syria and felt uncertain about their future.

According to Eurostat, 213,200 asylum seekers applied for protection in the EU during the second quarter of 2015 , representing an increase of $15 \%$ over the first quarter $(185,000)$ and $85 \%$ over the second quarter of $2014 .{ }^{14}$

The EU Commission declared tackling migration to be one of the EU's ten political priorities. A first implementation package on the European Agenda on Migration was adopted on 27 May 2015 including:

- a proposal to trigger for the first time Article 78(3) of the Treaty on the Functioning of the European Union in order to urgently relocate 40,000 asylum seekers for the benefit of Italy and Greece;

- a recommendation for a resettlement scheme for 20,000 persons from outside the EU;

- an action plan on smuggling;

- the necessary amendments to the EU budget to reinforce the Triton and Poseidon marine operations to save more lives.

A second implementation package was adopted by the Commission on 9 September 2015, proposing concrete measures to respond to the current refugee crisis and to prepare for future challenges, including:

\footnotetext{
${ }^{14}$ Eurostat, updated: 18/09/2015, in: ec.europa.eu/eurostat/documents/2995521/6996925/3-18092015BP-EN.pdf, downloaded: 30/10/2015.
} 
- an emergency relocation proposal for 120,000 persons in clear need of international protection from Greece, Hungary and Italy;

- a crisis relocation mechanism to be inserted into the Dublin Regulation;

- a common European list of Safe Countries of Origin;

- making return policy more effective through a common Return Handbook and an EU Action Plan on Return;

- a Communication on Public Procurement rules for Refugee Support Measures;

- a Communication on addressing the external dimension of the refugee crisis;

- $\quad$ an Emergency Trust Fund for Africa.

The EU budget was to provide dedicated funding of $€ 780$ million to support the relocation of 120,000 people, with hosting member satesreceiving $€ 6000$ per relocated person, including a $50 \%$ pre-financing rate to ensure that national authorities have the means to act very swiftly. Countries benefitting from the relocation will receive $€ 500$ for each person relocated to cover transport costs to the hosting member states.

Recent global developments have made Europe more secure for migrants. In itseconomic forecast for Fall 2015,the Commission argued that three million refugees and migrants could arrive in Europe by the end of $2017 .{ }^{15}$ The Syrian refugee crisis of 2015 highlighted how slowly EU member states are moving towards standardizing asylum policies and their inability to implement appropriate policies to manage the refugee crisis. Above all, the Syrian refugee crisis revealeddivisions in the EU's common foreign policy. The refugee crisis also showed that, as an international actor, the EU should take an active role in world politics and security issues. Closing Europe's doors and applying strict Schengen rules is not enough to keep EU secure. However, the most noteworthy point regarding Europe's refugee crisis is the absence of any long-term policy or common voice between member states.

\footnotetext{
${ }^{15}$ European Commission, European Economic Forecast, Autumn 2015, in: ec.europa.eu/economy_finance/publications/eeip/pdf/ip011_en.pdf, downloaded: 09/11/2015.
} 


\section{The Refugee Crisis on the European Union-Turkey Agenda}

Since the beginning of the crisis,the European Commission has contributed nearly $€ 51$ millionin humanitarian aid to assist Syrian and Iraqi refugees in Turkey. ${ }^{16}$ It has worked closely with the Turkish authorities, UN agencies and other humanitarian actors to meet the urgent humanitarian needs of new arrivals as well as the most vulnerable among the refugees:

- Approximately 45\% of new funds in 2015 target the health sector, especially physical rehabilitation and post-operative care, and primary health care services in acutely under-served areas.

- Humanitarian funding supports programmes that usecash or electronic vouchers, targeting assistance on the most vulnerable refugee families across Hatay, Kilis, Gaziantep, Sanliurfa, Mardin, Diyarbakir and Batman provinces.

- Through the EU,the Children of Peace initiative, Concern International and People in Need have been allocated new funds of up to $€ 850,000$ from the Commission in order to provide more Syrian children with access to schools, adding to the $€ 1.75$ million already committed under the initiative to UNICEF and Concern International in 2014.

- Programmes funded by other EU instruments, notably the $€ 13$ million contribution via the EU's Instrument for Pre-Accession Assistance (IcSP),continue to contribute to bolstering registration and access to health services for Syrian refugees through UNHCR. A further $€ 8.8$ million contribution channelled through the IcSPis supporting UNICEF's project to improve the resilience of vulnerable school-aged Syrian children and youth living in camps in Turkey, as well as funding UNHCR for its response to protection needs. Programming of further allocations under these instruments is also underway.

The Syrian refugee crisis was at the top of the agenda of EU-Turkey negotiationsfollowing the dramatic migration activity at the EU's borders in the summer of 2015. The Commission has engaged with Turkey to

\footnotetext{
${ }^{16}$ European Commission, Humanitarian Aid and Civil Protection, Turkey: Syria Crisis, ECHO Factsheet, http://ec.europa.eu/echo/files/aid/countries/factsheets/turkey_syrian_crisis_en.pdf, downloaded: 05/12/2015.
} 
strengthencooperation in support of Syrians under temporary protection and migration management in a coordinated effort to address the crisis created by the situation in Syria. This led to a Joint EU-Turkey Action Plan, agreed in October and activated at the EU-Turkey Summit on 29 November 2015. The plan aims to bring order to migratory flows and stem the influx of irregular migrants. On 24 November 2015, the Commission adopted a Commission Decision establishing a Turkey Refugee Facility to pool $€ 3$ billion additional resources, representing major additional support. This facility will coordinate and streamline actions financed from the EU's budget and bilateral contributions from EU member states to enhance the efficiency and complementarity of support provided to refugees and host communities in Turkey. ${ }^{17}$

The EU's approach to the crisis is paradoxical. On the one hand, its member states operate a protectionist migration policy.On the other hand,it has offered to open several new chapters for discussion within the accession negotiations framework on condition that the Syrian refugees are kept in Turkey. Such an approach reveals that that the EU classifies Turkey as a border country rather than candidate country, which conflictsboth with European membership principles andTurkey's membership prospects. Besides, the EU's conditional offer to the Turkish government about opening new chapters in return for a humanitarian response over the refugee crisis is consistent with neither EU norms nor Turkey's strategic membership goal. Instead, this issue should be handled within the framework of universal values by considering the dramatic dimensions of the Syrian civil war.

Another paradox is Merkel's visit on October 19, 2015 to Istanbul, which was perceived as providing opportunesupport for the Justice and Development Party (AKP) government just before general elections in Turkey.Despite the European Commission's suspicions about democracy in Turkey, Merkel's visit alsocontributing to shaping Turkey's futureover next five years, by turning the election atmosphere in favour of President Erdogan's party, the AKP.

As Syria enters its fifth year of war at the beginning of 2016 and there is no any serious progress toward peace,Turkey is no longer able to meet the expense of, or shoulder responsibility for hosting 2.2 million Syrian refugees.

\footnotetext{
${ }^{17}$ European Commission, European Neighbourhood Policy and Enlargement Negotiations, Countries: Turkey, İn: http://ec.europa.eu/enlargement/countries/detailed-countryinformation/turkey/index_en.htm, downloaded: 20/01/2016.
} 
However, the Syrian refugee issue does not only require financial burden sharing. It also carriesvarious political and social risks, which the EU is currently unwilling to accept. Indeed, closing its borders to the refugees and keeping them in Turkey under uncertain conditions will causesignificant long-term security problemsfor Europe since most Syrian refugees in Turkey are uneducated and unskilled. In addition, many are accommondated in Turkey's southeastern regions, which are already vulnerable to terrorism and separatism. An unplanned, mismanaged refugee crisis may increaseand spreadtension in a country thatshares common borders with EU member states.For many years, Turkey has been a buffer zone between the unstable Middle East and the EU. Considering that Turkey lacks the capacity, means or opportunity manage Syrian refugee migration alone, serious security problems in Turkey may develop in the future, which would cause social and political danger for theEUas well.

On the other hand, at the beginning of the conflict, Syrians also believed that they would only stay temporarily in Turkey before returning home. However, continued war has forced the refugees to consider a future outside Syria, recognizing that the conflict may last longer than expected. One of the main reasons Syrians have made the long and difficult journey to Europe is their mistrust ofthe proposal of international actors, including Turkey, to relocate them in a secure region to be established within Syria. Another factor pushing Syrians towards better conditions in Europe is that, even if the war ends quickly, reconstruction and rehabilitation will take years. Most would prefer to stay within Europe's borders because they assume that their ethnic rights will be better protected in Europe than in Turkey.

Overall,factors motivating Syrians to migrate to Europehave three main dimensions. The first is survival, which wasachieved by coming to Turkey. The second is economic and the third is social, for which Europe promises more than Turkey.

In response, the EU should develop a common refugee policy with Turkey since coordination and common policies will allow well-managed integration of refugees, decreasing the future risks for both sides. 


\section{Conclusion}

Migration is a key non-traditional security issue of the contemporary world as increasing international movements following the end of the Cold War due to a growth in armed conflicts and widening economic globalization.

The Arab Spring reached Syria in early 2011 after harsh measures taken by President Assad against nationwide protests demanding his resignation escalated tension. Anti-government attacksspreadthroughout the country, bringing it to what the United Nations in December 2011 called the verge of civil war. The Syrian conflict has become multifaceted with many factors, including international actors.

The cost of the fighting in Syria is dramatic, with more than 250,000 Syrians losing their lives in $41 / 2$ years of armed conflict while more than 11 million others have been forced from their homes. The largest number of officially registered Syrian refugees are in Turkey. During the summer of 2015, several EU member states were confronted with a significant increase in Syrian refugees at their borders, having crossed to Europe by sea and land.

The EU's 2013 Progress Report on Turkey included comments about the absence of comprehensive national strategy regarding the needs of Syrian refugees. However, developments in the summer of 2015 showed that neither the EU nor its member states have such a strategy themselves, preferring tosolve the Syrian refugee crisis by closing their borders and raising barriers.

Turkey, which shares common borders with EU member states, continues to host the most refugees. Moreover, since Turkey is a candidate country aiming to achieve full membership, the Syrian refugee issue should be considered within negotiations between the EU and a candidate country rather than between the EU and a border country.

Since it is impossible to estimate when the war in Syria will end because of the conflict's complexity, it is also difficult to foresee how long Syrian refugees willstay in Turkeyor other countries.Previous experience suggestsmanaging the refugees requires more detailed and better planned policies based on laws and regulations.

Of course, both Turkey and the EU should activelycontribute to establishing permanent peace and stability both in Syria and the Middle East to stem refugee 
flows from these geographies. This will require both sides to work hard with the international community.They should also develop common action plans for effective refugee management whilenot only Turkey but also EU member states should prepare national level and EU level plans for successful migration management. EU memberstates have found it difficult to deal with migrants as the EU has not recovered from the 2008 economic crisis and is struggling with the consequences of sanctions against Russia. Nevertheless, these factors cannot justify the EU memberstatesclosing their borders during the worst refugee emergency since World War II.The proposals discussed here for both sides to deal with the Syrian refugee crisis under its existing conditions represent the best chance to avoid paying the price for the Syrian crisis by reducingthe risks of future uncontrolled refugee flows.

\section{References and notes:}

BBC News: Syria: The Story Of The Conflict, 09 October 2015, in: http://www.bbc.com/news/world-middle-east-26116868, downloaded: 10/11/2015.

Brenke, KARL: Distribution of Refugees Very Uneven Among EU Member States - Even When Accounting for Economic Strength and Total Population, DIW Economic Bulletin 39, pp.511-524, 2015.

Cornell University Library: Syria: Revolution 2011-, in: http://guides.library.cornell.edu/c.php?g=31688\&p=200753, downloaded: 10/11/2015.

European Commission: European Economic Forecast, Autumn 2015, in: ec.europa.eu/economy_finance/publications/eeip/pdf/ip011_en.pdf, downloaded: 09/11/2015.

European Commission, European Neighbourhood Policy and Enlargement Negotiations, Countries: Turkey, İn: http://ec.europa.eu/enlargement/countries/detailed-countryinformation/turkey/index_en.htm, downloaded: 20/01/2016.

European Commission, Humanitarian Aid and Civil Protection, Turkey: Syria Crisis, ECHO Factsheet, in: http://ec.europa.eu/echo/files/aid/countries/factsheets/turkey_syrian_crisis_en.pdf, downloaded: 05/12/2015.

European Commission: Refugee Crisis-Q\&A on Emergency Relocation, Brussels, 22/09/2015, in: http://europa.eu/rapid/press-release_MEMO-15-5698_en.htm, downloaded: $12 / 11 / 2015$.

Eurostat: Updated: 18/09/2015, in: ec.europa.eu/eurostat/documents/2995521/6996925/318092015-BP-EN.pdf, downloaded: 30/10/2015.

Forced Migration Online, in: http://www.forcedmigration.org/about/whatisfmhttp://www.forcedmigration.org/ab out/whatisf, downloaded: 07/11/2015.

Ghimis, ANDREIA and Pascouau, YVES: EPC Policy Update for the European 
Programme for Integration and Migration, European Policy Center, October 2015, in: http://www.epim.info/wp-content/uploads/2015/10/EPIM-EPC-

Update_OCTOBER2015.pdf, downloaded: 07/11/2015.

Girit, SELIN: “Syrian Refugee File: Did The Visit Extend?", BBC İstanbul, 5/10/2015, in: http://www.bbc.com/turkce/haberler/2015/10/151005_suriyeli_multeciler, downloaded: 03/11/2015.

Icduygu, AHMET: Syrian Refugees In Turkey: The Long Road Ahead, Transatlantic Council On Migration, Migration Policy Institute, April 2015, in: http://www.migrationpolicy.org/research/syrian-refugees-turkey-long-road-ahead, downloaded: 31/10/2015.

International Organization for Migration: Essentials of Migration Management, Volume 1, Migration Management Foundation, Section 1.3 Migration and History in: http://www.rcmvs.org/documentos/IOM_EMM/v1/volume1.html, downloaded: $07 / 11 / 2015$.

International Strategic Research Organisation, "Refugee Crisis and A Risk of Axis Shift In Turkey - the EU Relations", USAK Report No 29, 2015, in: http://usak.org.tr/images_upload/files/Book\%201e.pdf, downloaded: 26/10/2015.

Kanat, KILIÇ BUGRA; Ustun, KADIR: Turkey's Syrian Refugees: Toward Integration, SETA, Ankara, 2015.

Kap, DERYA: Syrian Refugees: Turkey’s Future Citizens, Akademik Perspektif, December 2014, in: http://akademikperspektif.com/2015/01/19/suriyeli-multeciler-turkiyeninmustakbel-vatandaslari/, downloaded: 10/11/2015.

Kurtulus, BEGUM: Victims of the War: Turkey's Syrian “Guests”, Electronic Journal of Political Science Studies, Volume:6 No:2, pp. 45-60, June 2015.

Latif, DILEK: Refugee Policy Of The Turkish Republic, Turkish Yearbook of International Relations, Volume 33, p. 2-29, 2002. in:

http://dergiler.ankara.edu.tr/dergiler/44/673/8567.pdf, downloaded: 02/11/2015.

Ministry of Interior of Republic of Turkey, Directorate General of Migration Management: Syrian Nationals Benefiting from Temporary Protection in Turkey, updated: 09/07/2015, in: http://www.goc.gov.tr/icerik3/gecici-korumamiz-altindakisuriyeliler_409_558_560, dpwnloaded: 14/11/2015.

Oner, N. ASLI SIRIN; Genc, DENIZ: Vulnerability Leading to Mobility: Syrians’ Exodus fromTurkey, Migration Letters, Volume: 12, No: 3, pp. 251 - 262, September 2015.

Oxford Dictionaries, in: http://www.oxforddictionaries.com/definition/english/migration, downloaded: 07/11/2015.

Radikal: Erdogan's Refugee Message To The Europe, 13/11/2015, in: http://www.radikal.com.tr/turkiye/erdogandan-avrupaya-multeci-mesaji-1471665/, downloaded: 05/11/2015.

Republic of Turkey, Official Gazette No 28615,Law of Foreigners and International ProtectionNo 6458, Approval Date: 04/04/2013, in: http://www.resmigazete.gov.tr/eskiler/2013/04/20130411-2.htm, downloaded: 05/11/2015.

Temporary Protection Regulation, in: http://www.goc.gov.tr/files/_dokuman28.pdf, downloaded: 05/11.2015.

Tolay, JULIETTE: The EU and Turkey's Asylum Policies in the Light of the Syrian Crisis, Global Turkey in Europe, Policy Brief 10, January 2014.

Turkish Red Crescend: Syria Humanitarian Aid Operation, June 2015, in: https://www.kizilay.org.tr/KizilayMedya/Reader/31, downloaded: 29/10/2015. 
United Nations Development Programme: Syria: Alienation and Violence, Impact of Syria Crisis Report 2015, March 2015, in:

http://www.unrwa.org/sites/default/files/alienation_and_violence_impact_of_the_s yria_crisis_in_2014_eng.pdf, downloaded: 10/11/2015.

United Nations High Commissioner for Refugees: Syria Regional Refugee Response (updated 03 November 2015), in: http://data.unhcr.org/syrianrefugees/regional.php, downloaded: 07/11/2015.

United Nations Human Rights: The Independent International Commission of Inquiry on the Syrian Arab Republic, in:

http://www.ohchr.org/en/hrbodies/hrc/iicisyria/pages/independentinternationalcom mission.aspx, downloaded: 05/11/2015.

United Nations Statistical Commission and Statistical Office of the UN Economic

Commissionfor European Communities (EUROSTAT), Conference of European

Statisticians: Is The Measurement Of International Migration Flows Improving In

Europe, Submitted by Belgium, Geneva, 21-23 May 2001, in:

http://www.unece.org/stats/documents/2001/05/migration/12.e.pdf, downloaded:

03/11/2015.

\title{
Summary
}

\section{The Syrian Refugee Crisis: New Negotiation Chapter in European Union-Turkey Relations}

\author{
Ulviyye Aydin \\ Izmir University, Turkey
}

Syria is one of the countries where a revolution wave named Arab Spring uprose in early 2011. The most radical discourse from Arab Spring into the still ongoing civil wars took place in Syria as early as the second half of 2011. At the beginning it was a civil protest against Assad's government. Nobody could not estimate the future developments in Syria. The cost of the war in Syria increases every day. More than 250,000 Syrians have lost their lives in four-and-a-half years of armed conflict, which began with anti-government protests before escalating into a full-scale civil war. More than 11 million others have been forced from their homes as forces loyal to President Bashar al-Assad and those opposed to his rule battle each other - as well as jihadist militants from Islamic State. Mixed featured developments and longer resistance of Assad's regime than estimated escalated tension in Syria in last four and half years. As a result, many countries in the Middle East, such as Egypt, Iraq, Jordan and Lebanon, also Turkey, Serbia, Germany, Sweden, Hungary, Austria, Netherlands, Bulgaria are the sides that should pay a cost of the Syrian war. These states spend a remarkable budget for the Syrian refugees. Economic expenditure is just one dimension of Syrian refugee crisis. Movement of Syrian refugees to the European countries passing Turkish borders is one of the biggest migration crisis of the modern world history. Considering multifaced impacts of the migration, the aim of this paper is to analyze the Syrian refugee crisis as a new negotiation headline between the Europan Union and Turkey.

Keywords: European Union, migration, Syrian Refugees, Turkey 